\title{
Lactose utilization and enzymes encoded by megaplasmids in Rhizobium meliloti SU47: implications for population studies
}

\author{
Trevor C. Charles, Rama S. Singh and Turlough M. Finan* \\ Department of Biology, McMaster University, 1280 Main Street West, Hamilton, Ontario, Canada L8S 4 KI
}

(Received 21 March 1990; revised 25 June 1990; accepted 9 August 1990)

\begin{abstract}
Cell extracts prepared from Agrobacterium tumefaciens GMI9023 derivatives carrying megaplasmids from Rhizobium meliloti strain SU47 were examined by non-denaturing polyacrylamide gel electrophoresis and subsequent specific enzyme staining. The results demonstrated that an unidentified or 'nothing' dehydrogenase is encoded by the nod-nif megaplasmid pRmeSU47a, and a $\beta$-galactosidase activity that is required for growth on lactose as sole carbon source is encoded by the exo-thi megaplasmid pRmeSU47b. These results are of particular importance regarding the choice of markers used in bacterial population genetic studies.
\end{abstract}

\section{Introduction}

Enzyme electrophoresis is commonly used in bacterial population genetics (Selander et al., 1986), and in Rhizobium it has been used in the study of indigenous soil populations (Young, 1985). A recent survey (Young, 1985) of isolates from lucerne nodules assigned $R$. meliloti strains to two main groups, a major distinguishing factor being the presence of two $\beta$-galactosidase activities in members of one group, and only one $\beta$-galactosidase activity in members of the other. Two $\beta$-galactosidase activities, one constitutive and one inducible, have previously been reported in the $R$. meliloti SU47 derivative Rm2011 (Niel et al., 1977). Only the inducible enzyme activity could support growth on lactose, therefore mutants lacking the inducible enzyme could not use lactose as sole carbon source although the constitutive $\beta$-galactosidase activity of the second enzyme remained.

Most strains of $R$. meliloti are known to carry two megaplasmids, each of which exceeds $1000 \mathrm{~kb}$ in size (Banfalvi et al., 1985; Bromfield et al., 1987; Burkhardt et al., 1987; Hynes et al., 1986; Rosenberg et al., 1981, 1982). In $R$. meliloti SU47 the two megaplasmids have been designated $\mathrm{pRmeSU} 47 \mathrm{a}$ and $\mathrm{pRmeSU} 47 \mathrm{~b}$. Among

\footnotetext{
Abbreviations: MTT, 3-(4,5-dimethyl-2-yl)-2,5-diphenyltetrazolium bromide; ONPG, $o$-nitrophenyl $\beta$-D-galactopyranoside; PMS, phenazine methosulphate.
}

the limited number of genes known to be carried on the megaplasmids are nodulation (nod) and nitrogen fixation (nif) genes on pRmeSU47a (Banfalvi et al., 1981; Rosenberg et al., 1981), and $\mathrm{C}_{4}$-dicarboxylate transport (dct), exopolysaccharide and thiamin biosynthesis genes on pRmeSU47b (Finan et al., 1986; Hynes et al., 1986; Watson et al., 1988). In the course of a survey of the genetic structure of $R$. meliloti strains using enzyme electrophoresis, we included an $R$. meliloti SU47 derivative and Agrobacterium tumefaciens strains carrying megaplasmid pRmeSU47a or pRmeSU47b, or no plasmid. Thus we were able to differentiate between chromosomal and megaplasmid-encoded enzymes. Here we present evidence that a $\beta$-galactosidase enzyme is encoded by genes carried on the $R$. meliloti exo-thi-dct megaplasmid pRmeSU47b, and determine the position of this gene on the recently constructed genetic map of pRmeSU47b (Charles \& Finan, 1990). In addition, we show that an unidentified or 'nothing' dehydrogenase activity (Selander et al., 1986) is encoded by the nod-nif megaplasmid $\mathrm{pRmeSU} 47 \mathrm{a}$.

\section{Methods}

\author{
Bacterial strains. These are shown in Table 1.
}

Media, antibiotics and growth conditions. Bacteria were cultured in LB (Miller, 1972), LBmc (Finan et al., 1984) or M9 salts (Miller, 1972) supplemented with $0.25 \mathrm{~mm}-\mathrm{CaCl}_{2}, 1 \mathrm{~mm}-\mathrm{MgSO}_{4}, 15 \mathrm{~mm}$-glucose or 
Table 1. Bacterial strains

\begin{tabular}{|c|c|c|}
\hline Strain & $\begin{array}{l}\text { Relevant } \\
\text { characteristics* }\end{array}$ & $\begin{array}{l}\text { Source } \\
\text { or reference }\end{array}$ \\
\hline \multicolumn{3}{|c|}{ Rhizobium meliloti } \\
\hline RM1021 & SU47 str-21 & Meade et al. (1982) \\
\hline RmF416 & $\operatorname{Rm} 1021$, lac-416:: $\operatorname{Tn} 5$ & This work \\
\hline $\mathrm{RmF} 417$ & $\operatorname{Rm} 1021, l a c-417:: \operatorname{Tn} 5$ & This work \\
\hline Rm5455 & Rm1021, lac-56:: Tn5 & Charles \& Finan (1990) \\
\hline GMI214 & $\begin{array}{l}\text { SU47 deleted of the nod-nif region of } \\
\text { pRmeSU47a }\end{array}$ & J. Denarie $†$ \\
\hline \multicolumn{3}{|c|}{ Agrobacterium tumefaciens } \\
\hline GMI9023 & $\begin{array}{l}\text { C58 cured of pTiC58 and pATC58, } \\
\mathrm{Sm}^{\mathrm{r}} \mathrm{Rf}^{\mathrm{r}}\end{array}$ & Rosenberg \& Huguet (1984) \\
\hline At125 & GMI9023, pRmeSU47b $\Omega 5007:: \operatorname{Tn} 5$-oriT & Finan et al. (1986) \\
\hline At128 & GMI9023, pRmeSU47a $\Omega 30:: \operatorname{Tn} 5-11$ & Finan et al. (1986) \\
\hline \multicolumn{3}{|c|}{ Escherichia coli } \\
\hline
\end{tabular}

* Abbreviations for antibiotics are as follows: Rf, rifampin; Sm, streptomycin.

† Laboratoire de Biologie Moléculaire des Relations Plantes-Microorganismes, CastanetTolosan Cedex, France.

$5 \mathrm{~mm}$-lactose as carbon source, and $0.3 \mathrm{mg}$ of biotin per litre. Thiamin was used at $5 \mu \mathrm{M}$ and proline was used at $2 \mathrm{~mm}$ when required. Antibiotics were used at the following concentrations for $R$. meliloti $\left(\mu \mathrm{g} \mathrm{ml}^{-1}\right)$ : gentamicin, 20; neomycin, 200; oxytetracycline, 0.3-0.5; spectinomycin, 100 ; streptomycin, 200 ; tetracycline, $10 . R$. meliloti was grown at $30^{\circ} \mathrm{C} ; E$. coli was grown at $30^{\circ} \mathrm{C}$ or $37^{\circ} \mathrm{C}$.

Enzyme electrophoresis. Cell-free extracts were prepared from cultures by sonication in sonication buffer $(20 \mathrm{~mm}-\mathrm{Tris} / \mathrm{HCl} \mathrm{pH} 7 \cdot 4$, $1 \mathrm{mM}-\mathrm{MgCl}_{2}, 0.1 \mathrm{~mm}$-dithiothreitol) followed by centrifugation to remove cell debris. The extracts were electrophoresed at $4{ }^{\circ} \mathrm{C}$ in $7 \%$ $(\mathrm{w} / \mathrm{v})$ native acrylamide gels using Tris/borate/EDTA buffer, $\mathrm{pH} 8.9$ ( $81 \mathrm{mM}$-Tris, $21 \mathrm{~mm}$-boric acid, $1.5 \mathrm{~mm}$-disodium EDTA) at $150-300 \mathrm{~V}$ for $4-5 \mathrm{~h}$ at $4{ }^{\circ} \mathrm{C}$, then stained for $\beta$-galactosidase or dehydrogenase activity. $\beta$-Galactosidase activity was detected after incubation in a $0.17 \mathrm{mg} \mathrm{ml}^{-1}$ solution of $4-O$-methylumbelliferyl $\beta$-D-galactoside in citrate/phosphate buffer, pH 4.5. The citrate/phosphate buffer contained $5.13 \mathrm{~g}$ citric acid and $12.5 \mathrm{~g}$ dibasic sodium phosphate heptahydrate $1^{-1}$ (Harris \& Hopkinson, 1976). Fluorescent bands were visualized under short-wavelength UV on a transilluminator. Dehydrogenase activity was detected by incubating the gel in $0 \cdot 1 \mathrm{M}$-Tris $/ \mathrm{HCl}$ pH 7.4 containing $3 \mathrm{~mm}-\mathrm{MgCl}_{2}, 50 \mathrm{mM}-\mathrm{KCl}, 0.3 \mathrm{mg}$ NAD or NADP $\mathrm{ml}^{-1}, 0.3 \mathrm{mg}$ 3-(4,5-dimethyl-2-yl)-2,5-diphenyltetrazolium bromide (MTT) $\mathrm{ml}^{-1}$ and $0.04 \mathrm{mg}$ phenazine methosulphate (PMS) $\mathrm{ml}^{-1}$, plus substrate (100 mM-sodium L-malate for malic enzyme) if required (Harris \& Hopkinson, 1976).

$\beta$-Galactosidase assay. Cultures were grown overnight in LBmc, then subcultured $1: 5$ into LBmc or LBmc supplemented with $5 \mathrm{~mm}$-lactose and incubated for $4 \mathrm{~h}$ with aeration at $30^{\circ} \mathrm{C}$. Cells were washed and resuspended in $2 \mathrm{ml} \mathrm{Z}$ buffer (Miller, 1972), then permeabilized by treatment with one drop of SDS $(0.1 \%)$ and two drops of chloroform. $\beta$-Galactosidase activity was assayed at $30^{\circ} \mathrm{C}$ according to Miller (1972) using $o$-nitrophenyl $\beta$-D-galactopyranoside (ONPG) as substrate.

Genetic techniques. Transduction, plasmid conjugation and transposon Tn 5 mutagenesis using pRK602 were performed as described previously (Finan et al., 1984, 1986). Recombinant cosmids which complemented the lactose mutations were isolated from the pLAFR1 clone bank of Rm1021 (Friedman et al., 1982) as described previously (Finan et al., 1988) except that selection was on M9 medium containing 5 mm-lactose.

\section{Results and Discussion}

\section{Megaplasmid-encoded $\beta$-galactosidase}

When proteins from $R$. meliloti $\mathrm{Rm} 1021$ cells grown in LBmc medium were examined by polyacrylamide gel electrophoresis, two $\beta$-galactosidase activities were detected. Presumably these correspond to the 'inducible' and 'constitutive' $\beta$-galactosidase activities previously described in this strain (Niel et al., 1977). Extracts from cells grown in TY, a medium commonly used in Rhizobium population genetic studies (e.g. Eardly et al., 1990), also showed the two enzyme activities. For gels run with extracts from lactose-induced cells the intensity of staining of the lactose-inducible $\beta$-galactosidase was greater than that of the constitutive enzyme. Consequently photographs of such gels often showed only the inducible $\beta$-galactosidase band. Thus Fig. 1 shows that for lactose-grown cells of wild-type $R$. meliloti $\left(\mathrm{Rm} 1021=\mathrm{SU} 47 \mathrm{Sm}^{\mathrm{r}}\right)$ and $A$. tumefaciens GMI9023 there were single $\beta$-galactosidase bands of characteristic electrophoretic mobility. These bands correspond to the inducible enzyme. For $A$. tumefaciens At125 (and not At128), however, two bands corresponding in mobility to the $R$. meliloti and $A$. tumefaciens enzymes were present. This indicated that the inducible $\beta$-galactosidase of $R$. meliloti was encoded by pRmeSU $47 \mathrm{~b}$ and was expressed in $A$. tumefaciens.

To confirm that the inducible $\beta$-galactosidase gene was located on megaplasmid pRmeSU47b, two independent mutants, RmF416 and RmF417, unable to grow on M9 salts agar with lactose as sole carbon source were identified following $\operatorname{Tn} 5$ mutagenesis of $R$. meliloti $\mathrm{Rm} 1021$. In transduction from both strains, the $\mathrm{Lac}^{-}$ phenotype was $100 \%$ cotransducible with the neomycin 


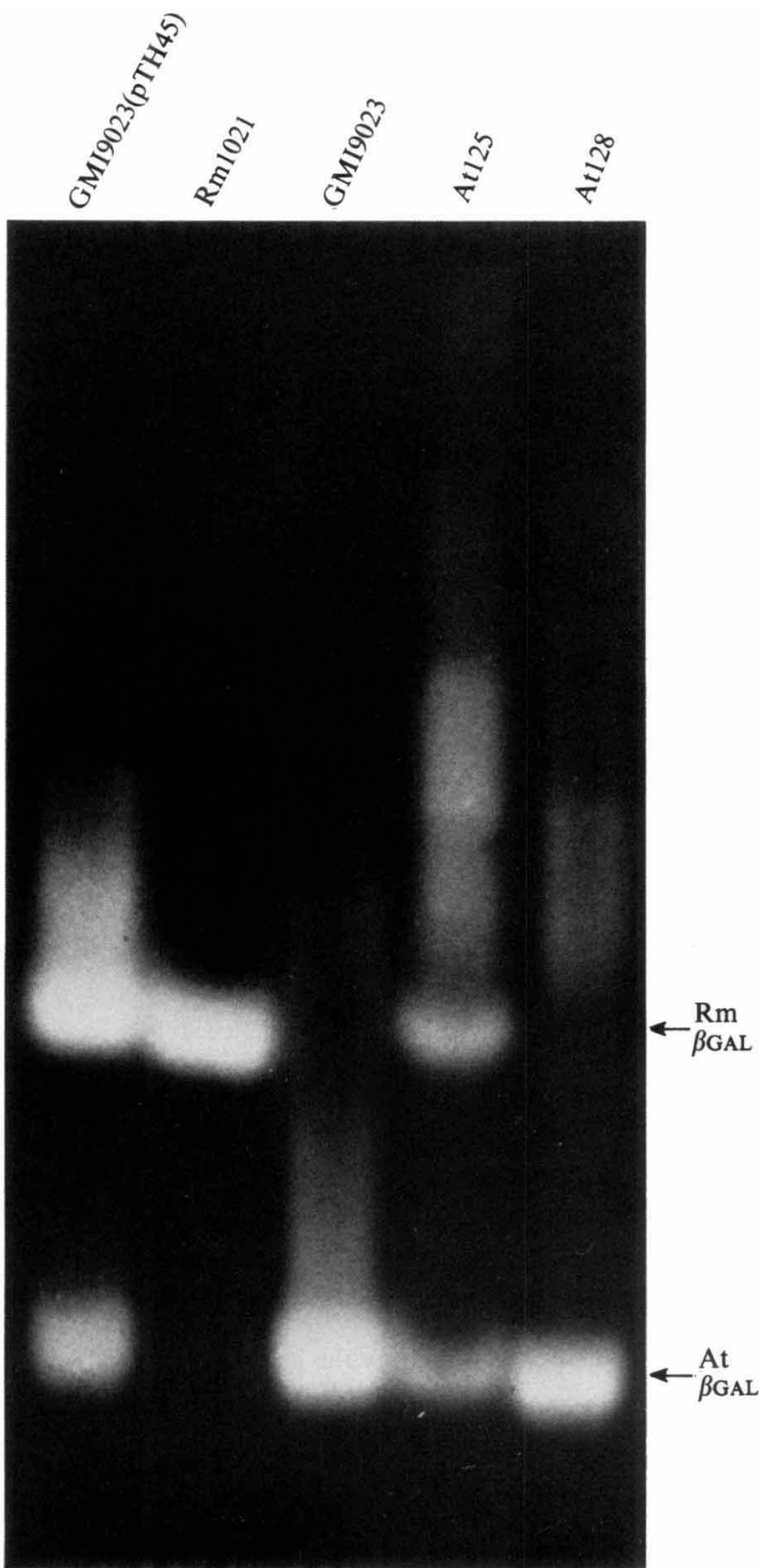

Fig. 1. Extracts of $R$. meliloti and A. tumefaciens strains separated on $7 \%$ acrylamide gels and stained for $\beta$-galactosidase. Upper and lower arrows indicate the inducible $R$. meliloti $(\mathrm{Rm})$, and $A$. tumefaciens (At) $\beta$-galactosidase $(\beta \mathrm{GAL})$ bands respectively.

resistance encoded by $\mathrm{Tn} 5$, indicating that the $\mathrm{Lac}^{-}$ phenotype resulted from the $\mathrm{Tn} 5$ insertion in both cases. The two mutations, designated lac-416::Tn5 and lac417:: $\operatorname{Tn} 5$, were mapped by three-factor $\phi \mathrm{M} 12$ transductional cross to transposon markers on pRmeSU $47 \mathrm{~b}$ and were found to lie between thi-502 and $\Omega 5079$ and to be $48 \%$ and $37 \%$ linked, respectively, to thi-502:: $\operatorname{Tn} 5-11$ (gentamicin-spectinomycin resistant; see Charles \& Finan, 1990, Fig. 2 and data not shown).

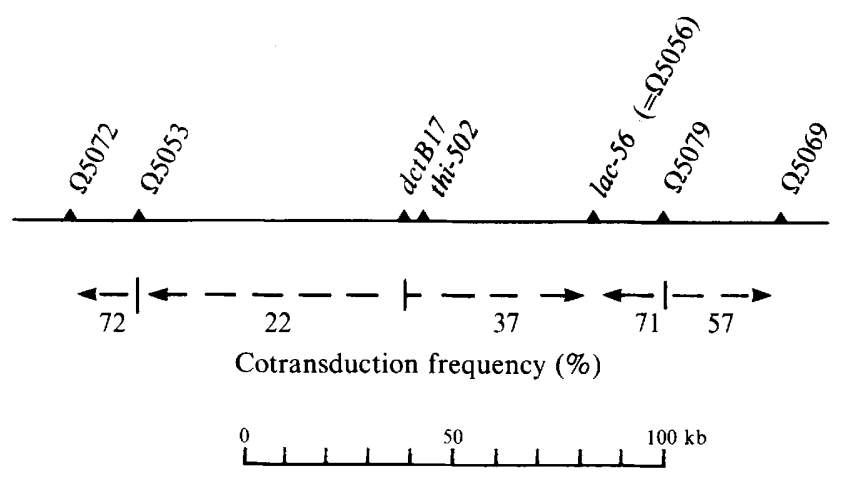

Fig. 2. Genetic map of part of pRmeSU47b showing the positions of $d c t$, thi and lac loci. The numbers below the arrows represent $\phi \mathrm{M} 12$ cotransductional frequencies $(\%)$, with the arrow tail indicating the selected marker and the arrow head indicating the unselected marker. The order and locations of transposon insertions (designated by $\Omega$ ) and $d c t$ and thi loci were previously determined (Charles \& Finan, 1990).

Table 2. $\beta$-Galactosidase activities of $R$. meliloti lac mutants

$\beta$-Galactosidase activities were determined, using ONPG as substrate, on cells grown in LBmc with or without supplemental lactose $(5 \mathrm{mM})$ as described in the text. Specific activities are expressed as Miller units (Miller, 1972). Values are the means of triplicate assays \pm standard error of the mean. Values with the same superscript letter are not significantly different at the $95 \%$ confidence level using Student's $t$-test.

\begin{tabular}{llr}
\hline \hline \multirow{2}{*}{ Strain } & \multicolumn{2}{c}{$\beta$-Galactosidase specific activity } \\
\cline { 2 - 3 } & Plus lactose & \multicolumn{1}{c}{ Minus lactose } \\
\hline RmF416 & $5 \cdot 93 \pm 0 \cdot 34^{b}$ & $5 \cdot 69 \pm 0 \cdot 31^{b}$ \\
RmF417 & $4 \cdot 80 \pm 0 \cdot 11^{a}$ & $5 \cdot 01 \pm 0 \cdot 10^{a}$ \\
Rm5455 & $4 \cdot 60 \pm 0 \cdot 54^{a}$ & $4 \cdot 98 \pm 0 \cdot 26^{a}$ \\
Rm1021 & $7 \cdot 18 \pm 0 \cdot 68^{c}$ & $10 \cdot 33 \pm 0 \cdot 69^{d}$ \\
\hline \hline
\end{tabular}

Examination of the recently constructed megaplasmid genetic map (Charles \& Finan, 1990) revealed that the previously isolated insertion, $\Omega 5056:: \operatorname{Tn} 5$, mapped in the lac region (Fig. 2). We subsequently found that strains carrying $\Omega 5056:: \mathrm{Tn} 5$ were $\mathrm{Lac}^{-}$(Table 2, $\mathrm{Rm} 5455=\mathrm{Rm} 1021 \Omega 5056:: \mathrm{Tn} 5)$. Insertion $\Omega 5056$ was designated as lac allele lac-56:: Tn 5 .

Results of $\beta$-galactosidase assays performed on the wild-type and the three mutants are presented in Table 2. For LBmc-grown cells, $\beta$-galactosidase activities of these mutants were significantly less than that of wild-type $\mathrm{Rm} 1021$, and no induction was seen in the presence of $5 \mathrm{~mm}$-lactose. The $\beta$-galactosidase activity of $\mathrm{Rm} 1021$ in $\mathrm{LBmc}+5 \mathrm{~mm}$-lactose was about twice that of the mutants grown in the same medium, and about $50 \%$ 
greater than that of $\mathrm{Rm} 1021$ grown in $\mathrm{LBmc}$ alone. Presumably the background activity of about 5 Miller units is due to the second, non-inducible, $\beta$-galactosidase, which does not allow growth on lactose. Similar data were previously obtained by Niel et al. (1977). Our results also suggest that the inducible $\beta$-galactosidase is expressed in LBmc medium even in the absence of added lactose. The significance of this is not clear as we have not done a systematic analysis of $\beta$-galactosidase expression in defined media.

Recombinant clones that restored lactose utilization ability to the mutants were isolated from a pLAFR 1 cosmid bank of Rm1021 DNA (Friedman et al., 1982). Restriction analysis identified three different plasmids, each of which carried common 5 and $7 \mathrm{~kb}$ EcoRI fragments (not shown). One of these, designated pTH45, was examined further. When extracts of $A$. tumefaciens GMI9023 containing pTH45 were examined by polyacrylamide gel electrophoresis a second $\beta$-galactosidase activity in addition to the Agrobacterium enzyme was detected (Fig. 1). The second band of activity had the same electrophoretic mobility as the inducible Rm1021 enzyme. Thus pTH45 carries the $R$. meliloti $\beta$-galactosidase enzyme structural gene. pTH45 failed to complement the Escherichia coli lac deletion mutant YMC9 for growth on M9 salts with lactose as sole carbon source, indicating that the inducible $R$. meliloti $\beta$-galactosidase is not expressed in $E$. coli. This is similar to the result recently reported by Fanning \& O'Gara (1988) for the cloned $\beta$-galactosidase-encoding gene of $R$. melilot $i$ $102 \mathrm{~F} 34$.

Plasmid-encoded lactose utilization genes have been found in other bacterial species and in some strains the lac genes are part of transposable elements (Cornelis $e t$ al., 1981). We have not examined the megaplasmid lac genes for the ability to transpose to other replicons. As plasmid-determined traits are generally considered to be unstable we note that in a previous survey eight out of eleven strains of $R$. meliloti examined could utilize lactose (Graham \& Parker, 1964). More recently, 28 strains of $R$. meliloti were found to form two major electrophoretic types which differed in glucose-6-phosphate dehydrogenase enzyme patterns and in the presence of one (15 strains) or two (13 strains) $\beta$-galactosidase enzymes (Young, 1985). In another recent survey of $232 R$. meliloti isolates two $\beta$-galactosidase isoenzymes were detected in $89 \%$ of the strains (Eardly et al., 1990). Unfortunately it is unclear which of the two $\beta$-galactosidase alleles in the above studies corresponds to the megaplasmid $\beta$ galactosidase allele. The presence of only one $\beta$ galactosidase activity in some strains would suggest that one or other of the two genes has been lost from some strains. It is also possible that some strains of $R$. meliloti have never acquired the second $\beta$-galactosidase enzyme.

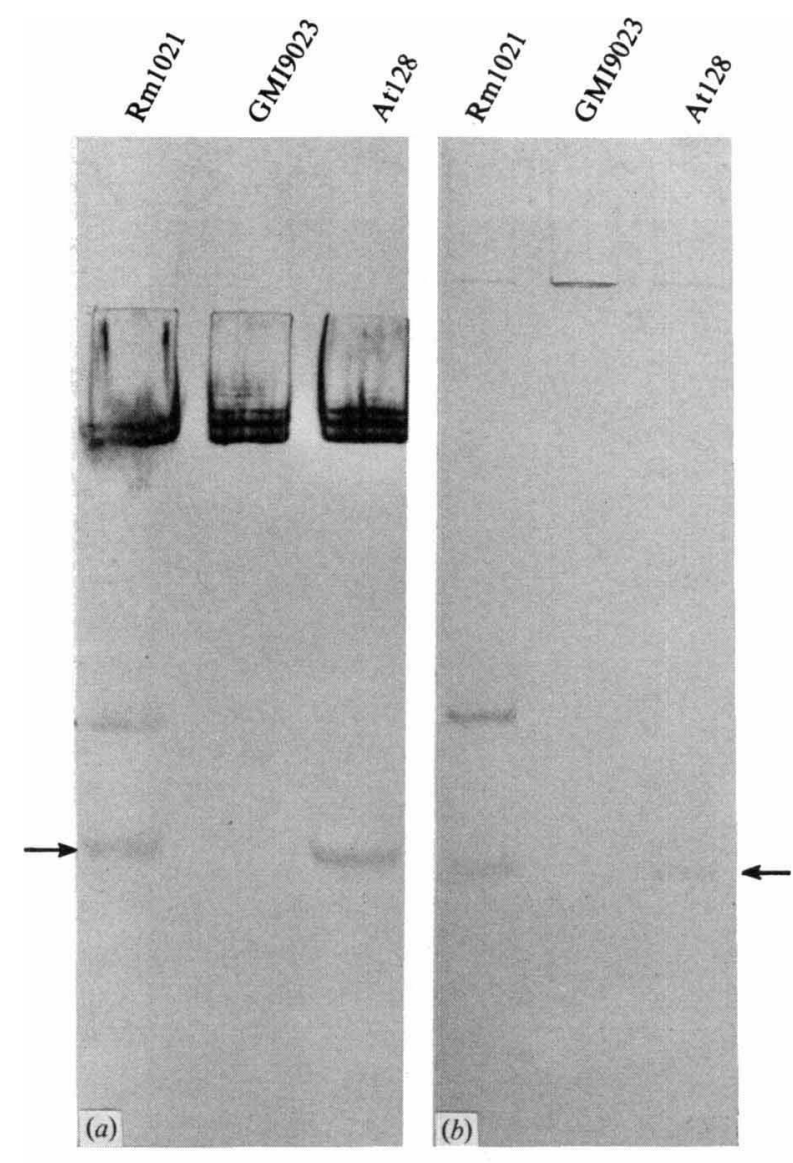

Fig. 3. Unidentified dehydrogenase activity associated with megaplasmid pRmeSU47a. Extracts of $R$. meliloti and A. tumefaciens strains were separated on $7 \%$ acrylamide gels and stained for malic enzyme, $(a)$ in the presence of NADP using L-malate as substrate, or $(b)$ with no added substrate and in the absence of NADP. The unidentified dehydrogenase band is indicated by the arrow.

Determination of these possibilities is important for understanding the genetic structure of natural populations of $R$. meliloti.

\section{Megaplasmid-encoded unidentified dehydrogenase}

While examining strains for various dehydrogenase activities by enzyme electrophoresis followed by specific enzyme staining in the presence of substrate, NAD or NADP, PMS and MTT, we observed that in addition to the specific enzyme activity, an additional band of characteristic mobility was present regardless what substrate was used. For example, when $R$. meliloti Rm1021 extract was stained for malic enzyme using L-malate as substrate, in addition to the malic enzyme band(s), there was also another band of greater electrophoretic mobility (Fig. $3 a$ ). This same enzyme activity was present in $A$. tumefaciens At128 (=GMI9023/ pRmeSU47a) extract but was absent in $A$. tumefaciens 
GMI9023 extract (Fig. $3 a$ ), suggesting that this second enzyme activity was encoded by pRmeSU47a. In other organisms, such activity is referred to as unidentified or 'nothing' dehydrogenase and has been used as an enzyme locus in population genetics studies (Selander et al., 1986). In further experiments we have found that the $R$. meliloti 'unidentified dehydrogenase' did not require NAD or NADP but did require PMS for the reduction of MTT (Fig. $3 b$ and not shown).

The unidentified dehydrogenase activity was present in extracts of the $R$. meliloti SU47 derivative GMI214, which is deleted of the entire pRmeSU47a nod-nif region (J. Denarie, personal communication). The activity was not detected in extracts of $\mathrm{Rm} 1021$ bacteroids (not shown). These data are consistent with the unidentified dehydrogenase not being directly involved in symbiosis, although they do not provide conclusive evidence for this.

\section{Enzymes not detected on megaplasmids}

In addition to the enzymes discussed above, it is worth noting that in our survey, expression of the following $R$. meliloti enzymes was not detected from megaplasmids in the Agrobacterium/megaplasmids hybrid strains (data not shown): 6-phosphogluconate dehydrogenase, glucose-6-phosphate dehydrogenase, isocitrate dehydrogenase, malate dehydrogenase, fumarase, phosphoglucose isomerase and tetrazolium oxidase.

\section{Concluding statements}

We have identified two enzyme activities associated with the megaplasmids of $R$. meliloti, and both of these activities are and have been used as markers in analyses of bacterial population structures. In fast-growing Rhizobium strains plasmid DNA constitutes a large fraction of the genome. Our results suggest that in these bacteria caution should be exercised in assuming that markers are chromosomally located unless this has been shown. In particular, it may be necessary to re-evaluate Rhizobium population genetic studies such as that of Young \& Wexler (1988) where $\beta$-galactosidase was used as a chromosomal marker.

We thank Attilio DiFiore, Sherrie Kerr, Patricia Liaw and Genghan Yan for technical assistance.

This work was supported by an operating grant from the Natural Sciences and Engineering Research Council of Canada to T.M.F.

\section{References}

Banfalvi, Z., Kondorosi, E. \& Kondorosi, A. (1985). Rhizobium meliloti carries two megaplasmids. Plasmid 13, 129-138.
Banfalvi, Z., Sakanyan, V., Koncz, C., Kiss, A., Dusha, A. \& KONDOROSI, A. (1981). Location of nodulation and nitrogen fixation genes on a high molecular weight plasmid of $R$. meliloti. Molecular and General Genetics 184, 318-325.

Bromfield, E. S. P., Thurman, N. P., Whitwill, S. T. \& Barran, L. R. (1987). Plasmids and symbiotic effectiveness of representative phage types from two indigenous populations of Rhizobium meliloti. Journal of General Microbiology 133, 3457-3466.

Burkardt, B., Schillik, D. \& Puhler, A. (1987). Physical characterization of Rhizobium meliloti megaplasmids. Plasmid 17, 13-25.

Charles, T. C. \& Finan, T. M. (1990). Genetic map of Rhizobium meliloti megaplasmid pRmeSU47b. Journal of Bacteriology 172, 2469-2476.

Cornelis, G., Sommer, H. \& SAEDler, H. (1981). Transposon Tn951 $(\operatorname{Tn} l a c)$ is defective and related to Tn3. Molecular and General Genetics 184, 241-248.

De Vos, G. F., Walker, G. C. \& Signer, E. R. (1986). Genetic manipulations in Rhizobium meliloti utilizing two new Tn 5 derivatives. Molecular and General Genetics 204, 485-491.

Eardly, B. E., Materon, L. A., Smith, N. H., Johnson, D. A., Rumbaugh, M. D. \& Selander, R. K. (1990). Genetic structure of natural populations of the nitrogen-fixing bacterium Rhizobium meliloti. Applied and Environmental Microbiology 56, 187-194.

FANNING, S. \& O'GARA, F. (1988). Cloning and characterization of a novel $\beta$-galactosidase-coding gene from Rhizobium meliloti. Gene 71 , $57-64$.

Finan, T. M., Hartwieg, E., Lemieux, K. Bergman, K., Walker, G. C. \& Signer, E. R. (1984). General transduction in Rhizobium meliloti. Journal of Bacteriology 159, 120-124.

Finan, T. M., Kunkel, B., De Vos, G. F. \& Signer, E. R. (1986). Second symbiotic megaplasmid in Rhizobium meliloti carrying exopolysaccharide and thiamine synthesis genes. Journal of Bacteriology 167, 66-72.

Finan, T. M., Oresnik, I. \& Bottacin, A. (1988). Mutants of Rhizobium meliloti defective in succinate metabolism. Journal of Bacteriology 170, 3396-3403.

Friedman, A. M., Long, S. R., Brown, S. E., Buikema, W. J. \& Ausubel, F. M. (1982). Construction of a broad host range cloning vector and its use in the genetic analysis of Rhizobium mutants. Gene 18, 289-296.

Graham, P. H. \& Parker, C. A. (1964). Diagnostic features in the characterization of the root-nodule bacteria of legumes. Plant and Soil 20, 383-396.

HARRIS, H. \& Hopkinson, D. A. (1976). Handbook of Enzyme Electrophoresis in Human Genetics. Amsterdam: North-Holland.

Hynes, M. F., Simon, R., Muller, P., Niehaus, K., Labes, M. \& PUHLER, A. (1986). The two megaplasmids of Rhizobium meliloti are involved in the effective nodulation of alfalfa. Molecular and General Genetics 202, 356-362.

Meade, H. M., Long, S. R., Ruvkun, G. B., Brown, S. E. \& Ausubel, F. M. (1982). Physical and genetic characterization of symbiotic and auxotrophic mutants of Rhizobium meliloti induced by transposon mutagenesis. Journal of Bacteriology 149, 114-122.

Miller, J. H. Experiments in Molecular Genetics. Cold Spring Harbor, NY: Cold Spring Harbor Laboratory.

Niel, C., Guillaume, J. B. \& BeChet, M. (1977). Mise en évidence de deux enzymes presentant une activité beta-galactosidasique chez Rhizobium meliloti. Canadian Journal of Microbiology 23, 1178-1181.

Rosenberg, C. \& Huguet, T. (1984). The pATC58 plasmid is not essential for tumour induction. Molecular and General Genetics 196, 533-536.

Rosenberg, C., Boistard, P., Denarie, J. \& Casse-Delbart, F. (1981). Genes controlling early and late functions in symbiosis are located on a megaplasmid in Rhizobium meliloti. Molecular and General Genetics 184, 326-333.

Rosenberg, C., Casse-Delbart, F., Dusha, I., David, M. \& BouCHER, C. (1982). Megaplasmids in the plant-associated bacteria Rhizobium meliloti and Pseudomonas solanacereum. Journal of Bacteriology 150, 402-406.

Selander, R. K., Caugant, D. A., Ochman, H., Musser, J. M., Gilmour, M. N. \& WhitTaM, T. S. (1986). Methods of multilocus 
enzyme electrophoresis for bacterial population genetics and systematics. Applied and Environmental Microbiology 51, 837-884.

Watson, R. J., Chan, Y-K., WheATCRoft, R., YANG, A-F. \& HAN, S. (1988). Rhizobium meliloti genes required for $\mathrm{C}_{4}$-dicarboxylate transport and symbiotic nitrogen fixation are located on a megaplasmid. Journal of Bacteriology 170, 927-934.
Young, J. P. W. (1985). Rhizobium population genetics: enzyme polymorphism in isolates from peas, clover, beans and lucerne grown at the same site. Journal of General Microbiology 131, 2399-2408.

YounG, J. P. W. \& WEXLER, M. (1988). Sym plasmid and chromosomal genotypes are correlated in field populations of Rhizobium leguminosarum. Journal of General Microbiology 134, 2731-2739. 